\title{
Cattle barn bedding from recycled manure: some veterinary, technological and economic aspects of application
}

\author{
Roman Uvarov ${ }^{1 *}$, Aleksandr Briukhanov ${ }^{1}$, Boris Semenov² and Anna Nazarova ${ }^{2}$ \\ ${ }^{1}$ Federal Scientific Agroengineering Center VIM, branch in Saint Petersburg, Russia \\ ${ }^{2}$ Saint-Petersburg State University of Veterinary Medicine, 196084 Saint-Petersburg, Russia
}

\begin{abstract}
Agriculture modernization is a topical issue for both the global and domestic economy. Intensification of livestock farming results in an increased production of manure. Recycling of manure into bedding is one of the modern utilization technologies. National regulations do not specify requirements for currently applied bedding types, including manure-based bedding. The foreign experience, however, demonstrates several economic, zootechnical and hygienic advantages of this material. The field veterinary study revealed the positive health effect of bedding. The cows housed without bedding featured threefold higher risk of surgical diseases of limbs. Technical and economic assessment of a dairy farm with 1000 dairy cows showed the following annual operating costs when the major part of manure was passively composted and a part of manure was recycled into the bedding by (1) aerobic solid-state fermentation in a chamber fermenter and finish drying in a dryer drum - 24.2 million roubles; (2) aerobic solid-state fermentation in a drum fermenter - 21.7 million roubles; and (3) thermal drying in a dryer drum - 27.5 million roubles. At the same time, if all manure produced was composted and the bedding was purchased from external sources, the costs would be 27.9 to 35.2 million roubles depending on the bedding material.
\end{abstract}

\section{Introduction}

Ensuring food security is one of the priority areas for global economic development. Adherence to the principles of sustainable nature management addresses this challenge avoiding the uncontrolled expansion of manufacturing capacities and subsequent waste disposal $[1,2]$.

Agriculture is the only economic sector that can provide the population with high-quality food. However, farming is inextricably linked with the production of not only the main types of products but a significant amount of waste. The main task of modern agroengineering science is to develop and test new, more efficient and environmentally friendly farming technologies based on smart use of natural resources [3].

The manure management problems are well known to specialists; the rest of the population, however, practically do not realize them and consider them insignificant. Meanwhile, in 2018, Russia produced 2.5 times more animal and poultry manure than the total crop and animal products (Table 1) [4].

Moreover, fresh animal and poultry manure are ranked to Hazard Classes 3 and 4, that is, to the substances that can only be used after they have been processed adequately $[3,5]$.
Table 1. Russian agricultural productivity indicators in 2018

\begin{tabular}{|l|c|}
\hline \multicolumn{1}{|c|}{ Product } & Produced, mln t \\
\hline Grain & 109.8 \\
\hline Sugar beet & 42.0 \\
\hline Potato & 22.4 \\
\hline Vegetables & 13.7 \\
\hline Milk & 30.6 \\
\hline Meat & 14.7 \\
\hline Animal/poultry manure & 581.2 \\
\hline
\end{tabular}

One of manure processing practices is aerobic solidstate fermentation. This method features high throughput, low operating costs and high quality of the resulting product [6-9], which has a broad application scope: from concentrated organic fertilizer to food additives for farm animals and poultry, as well as the bedding for cattle. Such processing considers manure not as waste, but as a secondary resource returning it to the production cycle and improving the general environmental compliance of production [3].

Cattle manure recycling into the bedding material is one of the environmentally friendly options of manure utilization. It is used in North America and Europe. In Russia, however, it is only starting to be introduced [10-13].

* Corresponding author: rauvarov@yandex.ru 
This study aimed to consider some veterinary, technological and economic aspects of manure-based bedding production technology in the conditions of the North-West of Russia.

\section{Materials and methods}

Relevant valid national regulations and guidelines were analyzed in terms of existing requirements for bedding for farm animals.

In 2016-2019 the physical condition of cow limbs, skin, joints and udder was assessed during the surgical medical examination of 6827 cows, including 2177 Ayrshire cows and 4650 Black-and-White cows, in 15 livestock complexes in Leningrad Region and the Republic of Belarus with the bedding and no-bedding housing systems.

The effect of various exogenous factors on the occurrence and progression of surgical diseases in cattle was estimated by the observation results.

The incidence rate of surgical limb diseases in cows with different housing systems was compared by Pearson's Chi-Squared Test $\left(\chi^{2}\right)$. The statistical significance (alpha level) adopted in this study was $5 \%$ $(\mathrm{p}=0.05)$.

The quantitative and physicochemical characteristics of the bedding were calculated and experimentally determined as part of the development of 16 technological manure handling regulations for livestock enterprises located in Leningrad, Kaliningrad and Novgorod Regions, the Republic of Karelia and Krasnoyarsk Territory.

The mass of required bedding for a livestock enterprise was calculated by the formula (1) [14]:

$$
M_{\text {tot }}=\left(M_{\text {first }}+M_{\text {daily }}\right) \cdot N_{\text {cow }} \cdot \mu \cdot t
$$

where $M_{\text {tot }}$ is a total mass of the bedding, $\mathrm{kg}$;

$M_{\text {first }}$ is the mass of the first bedding layer, $\mathrm{kg} / \mathrm{head}$;

$M_{\text {daily }}$ is the mass of daily bedding supply, $\mathrm{kg} / \mathrm{head}$;

$N_{\text {cow }}$ is the number of dairy cows, heads;

$\mu$ is a coefficient of non-lactating dairy cattle in the herd;

$t$ is time interval, day.

The volume of one-time bedding stock at the livestock enterprise was calculated by the formula (2) [14]:

$$
V_{\text {bedding }}=M_{\text {tot }} \cdot T_{\text {wint } e r} \cdot \beta \cdot \rho \text {, }
$$

where $V_{\text {bedding }}$ is the volume of the one-time bedding stock, $\mathrm{m}^{3}$;

$T_{\text {winter }}$ is the duration of winter in the region, day;

$\beta$ is the coefficient of bedding stock;

$\rho$ is the bedding density, $\mathrm{kg} / \mathrm{m}^{3}$.

The economic efficiency of the considered technologies was estimated by the standard methodology [15]. The purchase price of bedding materials (straw, sawdust, peat) was relevant for April 2020.

The data obtained was analysed in Microsoft Excel 2016, BioStat, AnalystSoft Inc.v.7.0 и StatGraphics Centurion v.16.1 software packages.

\section{Results and Discussion}

\subsection{Regulatory framework analysis}

At present, Russia has only one State Standard (GOST) that is indirectly related to bedding - GOST R 51661.2-
2000 "Peat for bedding. Specifications", according to which the norms are set for the following bedding material characteristics [16]:

- moisture content;

- ash content;

- moisture absorbing capacity;

- foreign material content (pieces of peat, tow, stumps, wood chips above $60 \mathrm{~mm}$ ).

However, there are no requirements associated with microbial and parasitic content in the bedding and some requirements, for example, to thermal conductivity, are advisory [17].

\subsection{The incidence of surgical limb diseases in cows}

The most common diseases in the examined animals are laminitis and bursitis of the tarsal joint (Fig. 1) [15].

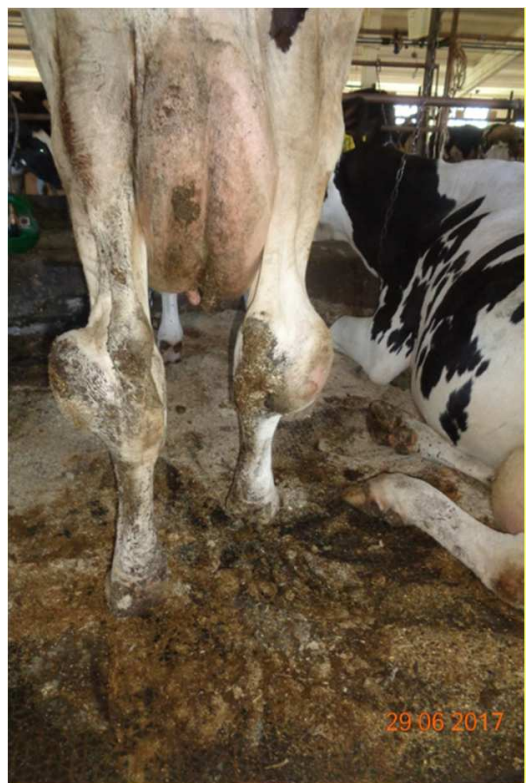

Fig. 1. Bursitis of the lateral subcutaneous bursa of the tarsal joints

The study of housing and feeding conditions of cows on industrial-scale complexes identified the etiological factors of the occurrence and progression of orthopedic diseases. Among these factors, the housing conditions had the most significant effect.

Prolonged keeping of cows in the stalls, combined with the absence of bedding or the bedding of poor quality, creates conditions for manure accumulation in the digit area resulting in the maceration of the hoof horn and loosening of the epidermis of the arch of the interdigital space and the coronary band.

Due to the tissues loosening the microtrauma occur. They are very quickly infected by the microorganisms from the bedding causing abscesses and phlegmon, including those of the coronary band. Subsequently, the soft and hard tissues are involved in the purulonecrotic processes, including the subcutaneous connective tissue of the axial side wall of the hoof, the sole, and further the pedal and short pastern bones and joints (Fig. 2). Suppurative arthritis and osteoarthritis develop. In some 
animals, there was observed a complete rejection of the horn shell of the pedal phalanx or the loss of the entire third phalanx of the digit.

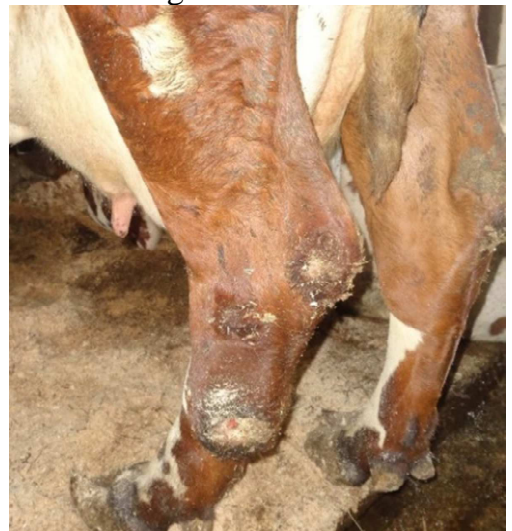

Fig. 2. Metatarsal periostitis

Housing of cows without any bedding is one of the etiological factors of Pododermatitis Circumscripta (Rusterholz ulcer) (Fig. 3), which may affect up to $56 \%$ of the herd [19].

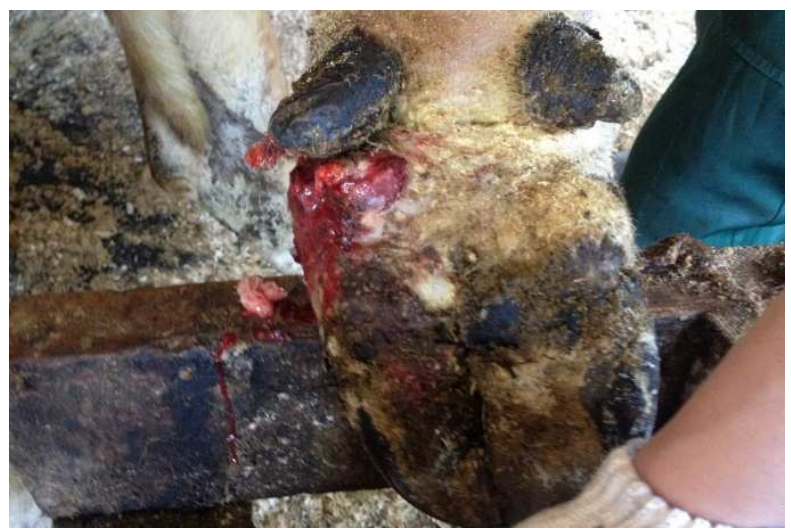

Fig. 3. Rusterholz Ulcer

Orthopedic pathologies cause a decrease in cow productivity. According to the study data, the productivity losses due to surgical limb diseases reach $30 \%$. Bred heifers with deformed hooves are often culled after the first lactation. This also entails significant economic losses to the farm.

A cow with a white line disease produces $570 \mathrm{~kg}$ less milk per lactation. Even subclinical hoof deformity (Fig. 4), in the absence of lameness, results in $4 \%$ to $14 \%$ lower cow productivity.

Limb diseases also affect the reproductive system of animals; for example, the service period becomes longer that may result in up to $17 \%$ of unborn calves.

Analysis of the results of surgical medical examination for diseases in the distal segments of limbs indicates a significant effect of the animal housing system, including the use of bedding, on the incidence of surgical limb diseases.

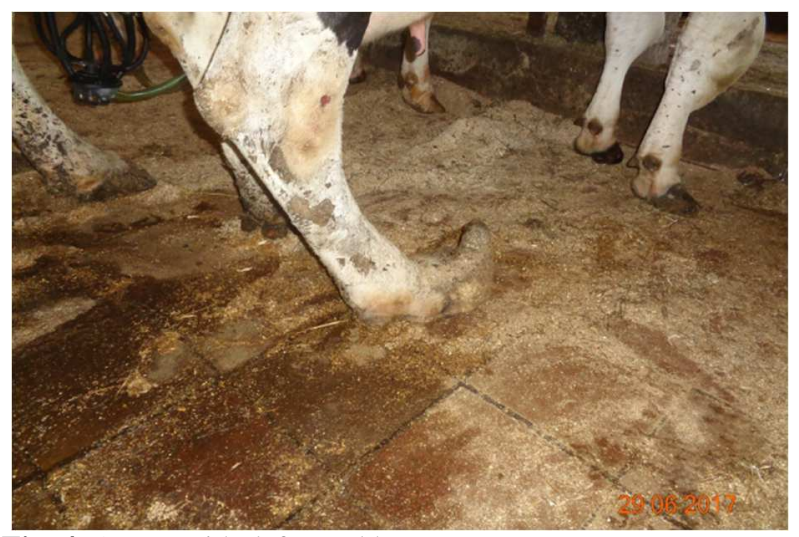

Fig. 4. A cow with deformed hooves

The study compared the incidence rate of limb diseases in cows with loose and tied housing on dairy complexes. In the loose housing system, there is either no bedding at all, or it is used only in the rest area. In the tied housing system, the bedding is, as a rule, provided.

In the loose housing system, the surgical diseases were diagnosed in $35.0 \%$ of examined cows, and in the tied housing system - in $10.5 \%$ of the examined cows. Based on the data obtained, the statistics contingency table was compiled (Table 2).

Table 2. Observed incidence rates of the limb diseases in cows

\begin{tabular}{|c|c|c|c|}
\hline $\begin{array}{c}\text { Housin } \\
\mathbf{g} \\
\text { system } \\
\mathbf{s}\end{array}$ & $\begin{array}{c}\text { Percentage } \\
\text { of animals } \\
\text { with surgical } \\
\text { diseases }\end{array}$ & $\begin{array}{c}\text { Percentage } \\
\text { of animals } \\
\text { without } \\
\text { surgical } \\
\text { diseases }\end{array}$ & $\begin{array}{c}\text { Tot } \\
\text { al }\end{array}$ \\
\hline Loose & 0.350 & 0.650 & 1 \\
\hline Tied & 0.105 & 0.895 & 1 \\
\hline TOTAL & 0.455 & 1.545 & 2 \\
\hline
\end{tabular}

Pearson's Chi-squared test $\left(\chi^{2}\right)$ was applied to assess the significance of differences in the incidence rate of surgical diseases of the distal segments of cow limbs in loose and tied housing systems.

$\mathrm{H}_{0}$ (null hypothesis) was that the housing system did not affect the incidence rate of surgical limb diseases. $\mathrm{H}_{1}$ (alternative hypothesis) was that the housing system affected the incidence rate of surgical limb diseases.

Degree of freedom for the created contingency table d.f. $=1$. The statistical significance (alpha level) adopted in this study was $5 \%(\mathrm{p}=0.05)$. According to the table of critical Chi-square values for d.f. $=1$ and $p=0.05$ the critical value of $\chi^{2}$ (Chi-square) was 3.84 for the created contingency table (Table 2) $\chi^{\mathbf{2}}=\mathbf{1 7 . 6 2}$, p-value $=2.69 \times 10^{-5}$.

Thus, the calculated $\chi^{2}$ was bigger than the critical value for the specified degree of freedom and the statistical significance of the study: $17.62 \gg 3.84$, and the p-value was significantly less than the specified significance level of $2.69 \times 10^{-5}<<0.05$. This allowed concluding that there was a statistically significant difference in the incidence rate of surgical limb diseases in cows in the loose (without bedding) and tied (with bedding) housing systems (the null 
hypothesis $\mathrm{H}_{0}$ rejected, the alternative hypothesis $\mathrm{H}_{1}$ accepted).

However, the condition of cow limbs is affected not only by availability or absence of bedding but also by its quality. Thus, the sawdust and chopped straw, which are most widely used on the farms as the bedding material, fail to create the optimal housing conditions.

For example, the high moisture content of bedding is one of the key factors in the development of purulonecrotic lesions of cow limbs (Fig. 5).

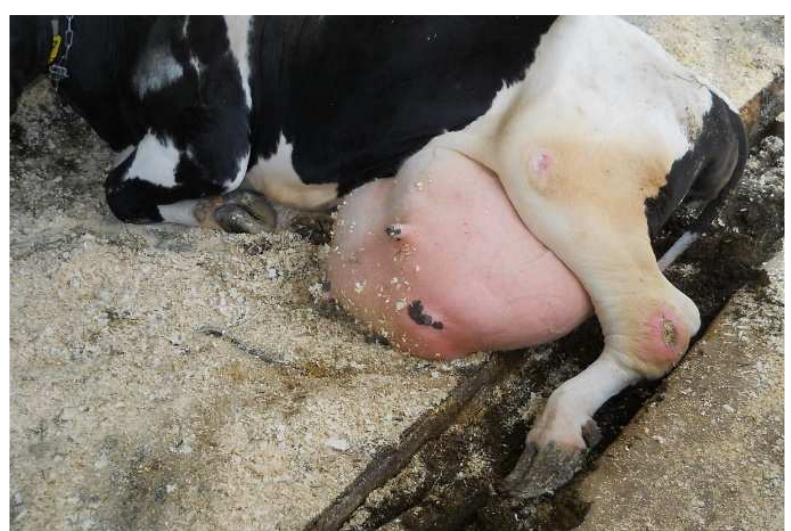

Fig. 5. Ulcers on the lateral surface of the knee and tarsal joints

Based on the above, the bedding should not only be in place but of certain quality providing the optimal housing conditions for the cattle in industrial-scale livestock complexes. The most common currently used bedding types do not meet all advanced requirements. Therefore, the present-day attention of veterinary specialists is focused on the bedding made from the recycled manure and on the development of its quality requirements.

\subsection{Available technologies for the bedding production from manure}

According to livestock specialists and veterinarians, the bedding for farm animals should basically not cause any harm to them and should feature the sufficient moisture absorbing capacity and low thermal conductivity [17, 20].

Thus, all available technologies for bedding production from manure come down to the isolation of the manure solid fraction and its subsequent thermal treatment.

Manure thermal treatment technologies applicable in climatic conditions under consideration are divided into two groups:

1) self-heating of the material through the activity of mesophilic and thermophilic microorganisms (solid-state fermentation);

2) heating of the material by external heat sources (thermal drying).

One of the leaders in the production of manure separators, FAN Separator from the Bauer Group, has designed a Green Bedding separator. They claim that the solid fraction of manure coming from this separator can be used as bedding without additional thermal treatment [21]. However, this is an option only if the initial manure is free from microbes and parasites that cannot be achieved under the conditions of the functioning livestock enterprise [10, 22-24].

The bedding production right on the farm has a significant advantage against the external sourcing - the zootechnical and veterinary services can continuously monitor the microbial and parasitic content of the material, thereby guaranteeing its safety for animals. Varying the operating mode of fermenters and driers allows producing the bedding with different characteristics for different age and gender animal groups.

According to the fermentation device type, there are drum (Fig. 6) and chamber (Fig. 7) biofermenters. The heating process in them is provided by creating the comfortable conditions for the life activity of microorganisms. Biofermenters have significantly lower operating costs against the drying units. The resulting product has the higher moisture content: the one coming from a drum fermenter - up to $50 \%$; the one coming from a chamber fermenter - up to $60 \%$. However, fermenters feature a longer processing time: drum fermenters - 3-4 days, chamber fermenters 7-9 days.

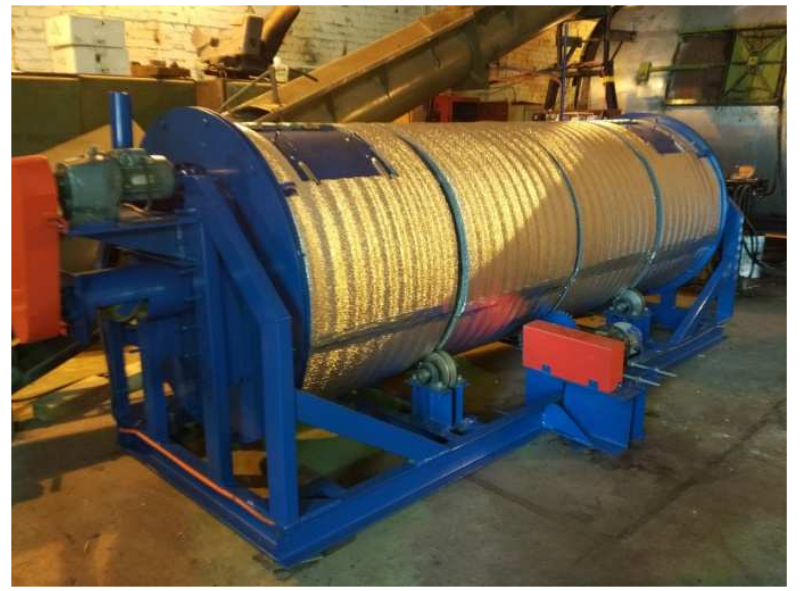

Fig. 6. Drum fermenter, BIOCON-AGRO, Russia

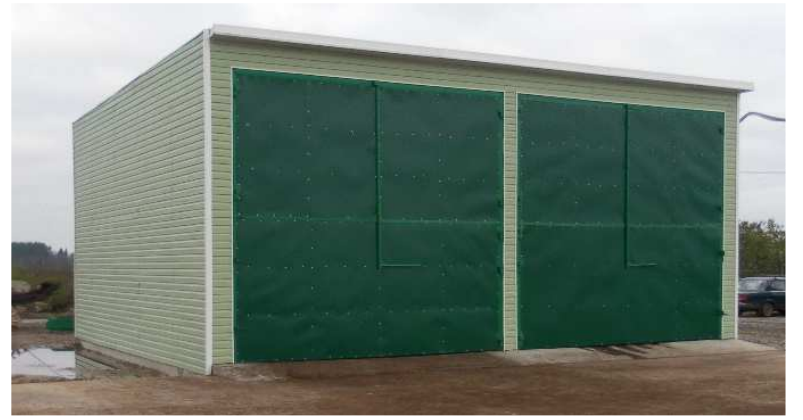

Fig. 7. Chamber fermenter, BIOZEM, Russia

The thermal drying is provided by supplying the heated air to the dryer drum, the drum rotation, gas removal and forced exhaust gas ventilation. Figure 8 shows the installation for animal/poultry manure drying.

Dryer drums can produce a product with up to $20 \%$ moisture content in a relatively short time - up to 48 hours. However, they have a significant drawback enormous capital and operating costs that make the 
agricultural application of thermal drying a low-return technology [3].

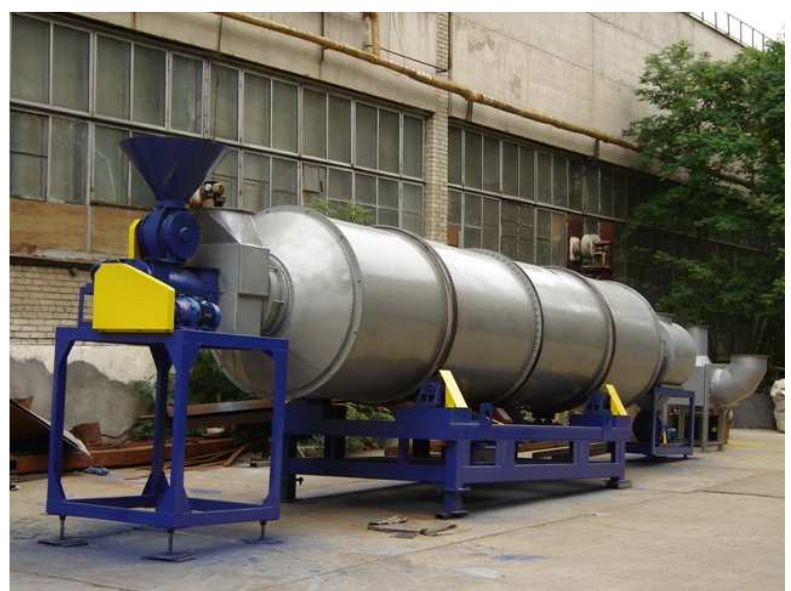

Fig. 8. Drying installation, TEPLOPROCESS, Russia

The bedding supply rates vary significantly with the animal housing system. As an example, the amount of bedding was calculated for a dairy farm for 1000 high producing cows with the milk yield over $6500 \mathrm{~kg} / \mathrm{cow} /$ year housed on bedding in the stalls. Table 3 shows the farm annual requirements for bedding from different materials.

Table 3. Annual bedding requirement of a dairy farm for 1000 cows

\begin{tabular}{|l|c|c|}
\hline Bedding material & $\begin{array}{c}\text { Required } \\
\text { bedding } \\
\text { amount, t/year }\end{array}$ & $\begin{array}{c}\text { One-time } \\
\text { bedding stock, } \\
\mathrm{m}^{3}\end{array}$ \\
\hline Straw & 651.0 & 2376.1 \\
\hline Saw dust & 1167.3 & 2130.3 \\
\hline Peat & 1818.2 & 2212.2 \\
\hline $\begin{array}{l}\text { Fermented } \\
\text { manure }\end{array}$ & 3097.8 & - \\
\hline
\end{tabular}

When using recycled manure as the bedding, the farm does not need the large stocks, since the source material is produced and processed into the bedding every day right in the farm territory.

The economic efficiency of the above processing technologies was estimated using the following parameters and conditions: the amount of manure produced was calculated by an approved method and amounted to $\mathbf{3 5 . 4}$ thousand tons/year [25]; the bulk of manure was processed by passive composting; specific operating costs for manure processing were as follows [3]:

- passive composting - $555 \mathrm{RUR} / \mathrm{t}$;

- solid-liquid separation - $150 \mathrm{RUR} / \mathrm{t}$;

- aerobic solid-state fermentation in a chamber fermenter - 862.5 RUR/t;

- aerobic solid-state fermentation in a drum fermenter - 1050 RUR/t;

- thermal drying - 3085 RUR/t.

Table 4 shows the estimation results.

\subsection{International experience}

The technology for cattle manure-based bedding production was first tested in the 1970s on the farms located in USA arid western regions [26]. Due to the high risk of bacterial load on animals, additional processing steps were included in the technology aimed at reducing the number of pathogens in the final product by increasing the temperature [27]. Further studies established that liquid-solid manure separation and thermal treatment of solids made the application of this technology possible in wetter and colder regions [11, 28-30].

Table 4. Operating costs of manure utilization and bedding procurement for a dairy farm with 1000 cows, million roubles per year

\begin{tabular}{|l|c|c|c|}
\hline & $\begin{array}{c}\text { Manure } \\
\text { utilizatio } \\
\text { n costs }\end{array}$ & $\begin{array}{c}\text { Bedding } \\
\text { procure } \\
\text { ment }\end{array}$ & $\begin{array}{c}\text { Total } \\
\text { costs }\end{array}$ \\
\hline \multicolumn{4}{|c|}{ Bedding procurement } \\
\hline Straw & 20.0 & 8.1 & 28.1 \\
\hline Saw dust & 20.3 & 7.6 & 27.9 \\
\hline Peat Bedding production & 35.2 \\
\hline \multicolumn{4}{|c|}{} \\
\hline $\begin{array}{l}\text { Fermentation } \\
\text { in a chamber } \\
\text { fermenter + } \\
\text { finish drying }\end{array}$ & 24.2 & - & 24.2 \\
\hline $\begin{array}{l}\text { Fermentation } \\
\text { in a drum } \\
\text { fermenter }\end{array}$ & 21.6 & - & 21.7 \\
\hline $\begin{array}{l}\text { Drying in a } \\
\text { dryer drum }\end{array}$ & 27.5 & - & 27.5 \\
\hline
\end{tabular}

In the past few years, this technology is gradually becoming more widespread in European countries. However, in the European Union there is no unified position on the use of recycled manure solids as bedding. According to EU Regulation 1069/2009, the cattle manure is a by-product classified as Category 2 material, therefore, its use as a "derived product" (for example, bedding) is allowed only under strict conditions minimizing the risk to public and animal health [33].

In general, the foreign researchers believe this practice to have several significant advantages: lower economic expenditures on bedding purchase and transportation, lower external supply dependency, weaker stresses associated with the housing systems and improved livestock health [10, 12, 32, 33].

\section{Conclusion}

The field study established the surgical limb diseases to be a serious problem in dairy farming. The presence or absence of bedding plays a significant role in the etiology of these diseases. The housing of cows without bedding leads to a sharp increase in the number of surgical diseases.

To date, sawdust, peat and straw are most commonly used as a bedding material in the region under consideration. However, under the intensive livestock 
farming conditions, they are not able to fully provide the optimal environment for keeping the highly producing cows resulting in their lower productivity. The bedding from recycled cattle manure has the required set of qualities to improve the animal welfare. The thermal treatment of manure guarantees its microbiological and parasitic purity; the sufficient moisture absorbing capacity and thermal conductivity allow to avoid the significant changes in the applied housing practices.

Many researchers are inclined to use the recycled cattle manure solids as bedding. In the countries of North America and Europe, this technology is finding wider application.

As part of the economic efficiency assessment, three manure-based bedding production technologies were considered:

- aerobic solid-state fermentation in a chamber fermenter and finish drying in a dryer drum;

- aerobic solid-state fermentation in a drum fermenter

- thermal drying in a dryer drum.

The operating costs for manure processing, with a part of it being recycled into the bedding, were found to be lower than the total costs for manure processing and the bedding procurement from external sources. Manurebased bedding production was found economically viable.

The line of further research is a comprehensive estimation of the technology for the bedding production from the recycled manure solids and its use on a functioning livestock complex as well as the development and substantiation of relevant requirements for various types of bedding, manure-based bedding, in particular.

\section{References}

1. The State of Food Security and Nutrition in the World 2018 (FAO, IFAD, UNICEF, WFP \& WHO, Rome, 2018) 128 p.

2. P. Larson, N. Larson, The hunger of nations: an empirical study of inter-relationships among the Sustainable Development Goals (SDGs), J. of Sustainable Developm., 12(6), 39-47 (2019)

3. A. Briukhanov, How to provide environmental compatibility of livestock and poultry farms: Best Available Techniques (IEEP, St. Petersburg, 2017) $296 \mathrm{p}$.

4. Unified Interdepartmental Information and Statistical System, Retrieved from: https://fedstat.ru/

5. Federal Classificatory Catalogue of Wastes, Retrieved from: https://fedstat.ru/

6. Manure Composting Manual (Alberta Agriculture, Food and Rural Development, Edmonton, 2005) $27 \mathrm{p}$.

7. V. Afanasjev, A. Afanasjev, I. Subbotin, Selection of the optimal manure utilization technology, Rural Mach. Oper., 4, 22-23 (2015)
8. R. Uvarov, A. Briukhanov, E. Shalavina, Study results of mass and nutrient loss in technologies of different composting rate: case of bedding poultry manure, Engineer. for Rural Developm., 15, 851857 (2016)

9. E. Shalavina, E. Vasilev, Study of bio-fermentation of organic waste from the pig complex with subsequent drying and granulation, Technol., Mach. and Equipment for Mechan. Crop and Livestock Product., 2(99), 310-317 (2019)

10. K. Leach, S. Archer, J. Breen et al., Recycling manure as cow bedding: potential benefits and risks for UK dairy farms, The Veter. J., 206(2), 123-130 (2015)

11. R. Uvarov, Research results of recyclability of solid cattle manure into bedding, Innovat. in Agricult., 5(15), 174-178 (2015)

12. S. Fournel, S. Godbout, P. Ruel et al., Production of recycled manure solids for use as bedding in Canadian dairy farms: II. Composting methods, J. of Dairy Sci., 102(2), 1847-1865 (2019)

13. L. Molina, E. Agüera, C. Pérez-Marín, F. MarotoMolina, Comparing welfare indicators in dairy cattle under different loose housing systems (deep litter vs cubicle barns) using recycled manure solids for bedding, Spanish J. of Agricult. Res., 18(1), 0501 (2020)

14. Management Directive for Agro-Industrial Complex RD-APK 1.10.01.01-18. Recommended Practice for Engineering Designing of Cattle Farms and Complexes (Rosinformagrotekh, Moscow, 2018) $167 \mathrm{p}$.

15. State Standard GOST 34393-2018. Agricultural machinery. Methods of economic evaluation (Standartinform, Moscow, 2018) $15 \mathrm{p}$.

16. State Standard GOST $R$ 51661.2-2000. Peat for litter. Specifications (Standartinform, Moscow, 2000) 5 p.

17. I. Kochish, N. Kaliuzhnyj, L. Volchkova, V. Nesterov, Veterinary hygiene (Lan, St. Petersburg, 2008) 464 p.

18. B. Semenov, V. Videnin, A. Batrakov et al., Etiology and treatment of extremities cows structure diseases in industrial complexes, Int. bull. of Veter. Med., 2, 122-129 (2018)

19. V. Rykol, A. Lyah, E. Hovaylo, Finger ulcers in cattle (etiopathogenesis, treatment and prevention): recommendations (VGAVM, Vitebsk, 2015) 29 p.

20. A. Sergienko, S. Psyukalo, V. Lukhanin, E. Usova, The study of the properties of bedding material for animals of the North Caucasus region, Polythem. online sci. J. of Kuban State Agrar. Univer., 109(05), 597-607 (2015)

21. Application of FAN Products, Retrieved from: https://www.fan-separator.de/

22. A. Vuorinen, M. Saharinen, Evolution of microbiological and chemical parameters during manure and straw co-composting in a drum 
composting system, Agricult., Ecosyst. \& Environ., 66(1), 19-29 (1997)

23. R. Uvarov, A. Briukhanov, I. Subbotin, E. Shalavina, Disinfection of solid fraction of cattle manure in drum-type bio-fermenter, Agron. Res., 15(3), 915-920 (2017)

24. S. Munshi, J. Roy, R. Noor, Microbiological investigation and determination of the antimicrobial potential of cow dung samples, Stamford J. of Microbiol., 8(1), 34-37 (2018)

25. A. Briukhanov, E. Shalavina, E. Vasilev, Methodology of integrated estimation of daily and annual output of animal/poultry manure, Dairy Newsletter, 1(13), 78-85 (2014)

26. J. Keys, L. Smith, B. Weinland, Response of dairy cattle given a free choice of free stall location and 3 bedding materials, J. of Dairy Sci., 59, 1157-1162 (1976)

27. E. Carroll, D. Jasper, Distribution of Enterobacteriaceae in recycled manure bedding on California dairies, J. of Dairy Sci., 61, 1498-1508 (1978)

28. J. Lendelová, M. Žitňák, M. Bošanský, M. Šimko, P. Piterka, Testing of property changes in recycled bedding for dairy cows, Res. in Agricult. Engineer., 62(SI), 44-52 (2016)

29. S. Lim, H. Park, X. Hao et al., Nitrogen, carbon, and dry matter losses during composting of livestock manure with two bulking agents as affected by coamendments of phosphogypsum and zeolite, Ecol. Engineer., 102, 280-290 (2017)

30. K. Patel, S. Godden, E. Royster et al., Relationships among bedding materials, bedding bacteria counts, udder hygiene, milk quality, and udder health in US dairy herds, J. of Dairy Sci., 102(11), 10213-10234 (2019)

31. M. Lasprilla-Mantilla, V. Wagner, J. Pena, A. Frechette et al., Effects of recycled manure solids bedding on the spread of gastrointestinal parasites in the environment of dairies and milk, J. of Dairy Sci., 102(12), 11308-11316 (2019)

32. B. Bromley, J. Oultram, Are recycled manure solids an appropriate bedding material for dairy cattle compared to traditional materials? Cattle Practice, 27(1), 26-40 (2019)

33. Regulation (EC) No1069/2009 of the European Parliament and of the Council of 21 October 2009, Retrieved from: https://eur-lex.europa.eu/legalcontent/EN/TXT/PDF/?uri=CELEX:32009R1069\&f rom=en 